\title{
COMPARATIVE EFFICACY OF 35\% GLYCOLIC ACID PEEL VS. 20\% SALICYLIC ACID PEEL IN THE TREATMENT OF POST ACNE SCARRING
}

\author{
Asmita Jha1, Karjigi Siddalingappa², Kallappa Herakal ${ }^{3}$,Karan Malhotra4, Harshavardhan Gowda 5 \\ 1Postgraduate Student, Department of Dermatology, Venereology and Leprosy, Navodaya Medical College Hospital and Research \\ Centre, Raichur, Karnataka. \\ 2Professor, Department of Dermatology, Venereology and Leprosy, Navodaya Medical College Hospital and Research Centre, Raichur, \\ Karnataka. \\ ${ }^{3}$ Professor and HOD, Department of Dermatology, Venereology and Leprosy, Navodaya Medical College Hospital and Research Centre, \\ Raichur, Karnataka. \\ ${ }^{4}$ Postgraduate Student, Department of Dermatology, Venereology and Leprosy, Navodaya Medical College Hospital and Research \\ Centre, Raichur, Karnataka. \\ 5Postgraduate Student, Department of Dermatology, Venereology and Leprosy, Navodaya Medical College Hospital and Research \\ Centre, Raichur, Karnataka.
}

\section{BACKGROUND}

\section{ABSTRACT}

Post acne scarring remains a common entity despite advances in the treatment of acne. A variety of modalities are available for post acne scarring, out of which chemical peels offer advantage of being non-invasive, painless, cheaper and easy to perform technique. Chemical peeling is the application of a chemical agent to the skin, causing controlled destruction of a part or whole of epidermis and/or a part of dermis.

Aims and Objectives- To compare the efficacy of GA 35\% vs. SA $20 \%$ in treatment of acne scars.

\section{MATERIALS AND METHODS}

This is a randomised comparative study of total 100 patients with post acne scarring. After taking the informed consent, they were randomised by computer generated random number table, which was allocated into 2 groups (50 each). One group received 35\% glycolic acid (GA) peel and other 20\% salicylic acid (SA) peel. A total of 3 sessions at an interval of 3 weeks. Response was graded on a five-point visual analogue scale. Since the calculated sample size was too high and thereby not feasible to include in this limited period of study, we had to limit the sample size for convenience.

\section{RESULTS}

Both SA and GA peels caused significant improvement in hyperpigmented scars. Although, SA peels had slightly better outcome when compared to GA peel, the difference was statistically not significant. The subjects found a greater final effect with SA, the mean score being 1.52 for GA peel and 1.92 for SA peel. Side effects were minimal and transient and there was no difference in the side effect profile between both the groups.

\section{CONCLUSION}

Both the agents (SA and GA) were equally effective and safe in Indian patients for post acne scarring and hyperpigmentation.

\section{KEY WORDS}

Post Acne Scarring, Chemical Peeling, Glycolic Acid Peel, Salicylic Acid Peel.

HOW TO CITE THIS ARTICLE: Jha A, Siddalingappa K, Herakal K, et al. Comparative efficacy of 35\% glycolic acid peel vs. 20\% salicylic acid peel in the treatment of post acne scarring. J. Evolution Med. Dent. Sci. 2018;7(19):2426-2428, DOI: $10.14260 /$ jemds/2018/545

\section{BACKGROUND}

'Scar' as a noun, is defined as the fibrous tissue that replaces normal tissue destroyed by injury or disease. Acne scarring begins with the evolution of acne lesions injury to skin inflammation, granulation tissue degradation of extracellular matrix. On the basis of net loss or gain of tissue scars are divided into: Hypertrophic scar and Atrophic scar- further divided by Jacob et al into: 1 . Ice pick Scar- 60-70\%, 2. Boxcar Scar- 20-30\% and 3. Rolling Scar- 15-25\%.1,2,3

'Financial or Other Competing Interest': None.

Submission 29-03-2018, Peer Review 24-04-2018,

Acceptance 30-04-2018, Published 07-05-2018.

Corresponding Author:

Dr. Asmita Jha,

D/o. Dr. S. N. Jha, B. N. Jha Road

(Opposite G. L. Motors), Deoghar-814112, Jharkhand.

E-mail: drasmitajha@gmail.com

DOI: $10.14260 /$ jemds $/ 2018 / 545$

Chemoexfoliation is an application of one or more chemical agents to the skin, so as to cause controlled destruction of a portion of the epidermis and/ or dermis. Chemoexfoliation leads to a dry desquamation or moist maceration, exfoliation resurfacing remodelling. Glycolic acid is also known as fruit peel is obtained from sugarcane. It is the most common alpha hydroxy peel used. Salicylic acid is a member of the Beta hydroxy acid group. Salicylic acid is derived from willow bark, wintergreen leaves and sweet birch. It crystallizes on face leaving a white coat- pseudo frost.

Aims and Objectives- To study and compare the efficacy of $35 \%$ glycolic acid peel with $20 \%$ salicylic acid peel in the treatment of post acne scarring.

\section{MATERIALS AND METHODS}

This is a randomised comparative study of 100 patients with post acne scars. After taking the informed consent they were 
randomised by computer generated random number table, which were divided into two groups consisting of 50 patients each. Group A contains 50 patients, of which 32 patients are females and 18 patients are males. Group B contains 50 patients, of which 36 are female patients and 14 are males. In this study, the sample size was taken for convenience.

\begin{tabular}{|c|c|c|c|c|c|}
\hline $\begin{array}{c}\text { Age } \\
\text { Distribution }\end{array}$ & Group A & & Group B & & P value \\
\hline Male & 32 & & 36 & & \\
\hline Female & 18 & & 14 & & \\
\hline Total & 50 & & 50 & & \\
\hline Mean \pm SD & $\begin{array}{c}18.3000 \pm \\
1.23\end{array}$ & 0.251 & $\begin{array}{c}16.0300 \pm \\
0.239\end{array}$ & 0.032 & 0.047 \\
\hline T-test value & \multicolumn{5}{|c|}{1.32} \\
\hline Table 1. Intragroup Comparison done by Pre-Peel Testing \\
\hline
\end{tabular}

After obtaining the written consent, history had been taken, clinical examination and global acne scarring classification done. Pre-peel testing done. Priming was done for all with $0.025 \%$ tretinoin cream for two weeks. They were advised to use a broad-spectrum sunscreen twice a day.4,5

Group A treated with $35 \%$ glycolic acid (GA) peel and Group B with 20\% salicylic acid (SA) peel. A total of 4 sessions at an interval of 3 weeks. Response was graded by objective assessment by comparing the changes in the Quantitative global acne scarring score at each visit and subjective assessment by five-point visual analogue scale. All the patients were followed up for 9 months.

\begin{tabular}{|c|c|c|c|c|c|c|c|c|c|}
\hline PEEL & $\begin{array}{c}\text { Change } \\
\text { Over } \\
\text { Baseline } \\
\text { Score }\end{array}$ & $\begin{array}{c}\text { Percentage of } \\
\text { Improvement } \\
\text { with GA Peel } \\
\text { (Group- A) }\end{array}$ & $\begin{array}{l}\text { “T” test } \\
\text { Value }\end{array}$ & $\begin{array}{l}\text { P value } \\
\text { (of GA) }\end{array}$ & $\begin{array}{l}\text { Change } \\
\text { Over } \\
\text { Baseline } \\
\text { Score }\end{array}$ & $\begin{array}{c}\text { Percentage of } \\
\text { Improvement } \\
\text { with SA Peel } \\
\text { (Group- B) }\end{array}$ & $\begin{array}{l}\text { P value } \\
\text { (of SA) }\end{array}$ & $\begin{array}{c}\text { P value } \\
\text { Gp 'A' vs. } \\
\text { Gp 'B' }\end{array}$ & $\begin{array}{l}\text { Results for } P \\
\text { value } \\
\text { (of GA) and } P \\
\text { value } \\
\text { (of SA) }\end{array}$ \\
\hline $1^{\text {st }}$ Peel & 0.14 & $0.76 \%$ & 0.2024 & 0.134 & 0.14 & 0.82 & 0.023 & 0.277 & 0.157 \\
\hline $2^{\text {nd }}$ Peel & 0.89 & $4.87 \%$ & 0.1295 & 0.00 & 1.09 & 6.39 & 0.00 & 0.198 & 0.00 \\
\hline 3rd Peel & 1.89 & $10.34 \%$ & 0.1235 & 0.000 & 2.11 & 12.31 & 0.000 & 0.188 & 0.00 \\
\hline \multirow[t]{2}{*}{$4^{\text {th }}$ Peel } & 2.84 & $15.54 \%$ & 0.1268 & 0.000 & 3.00 & 17.5 & 0.000 & 0.190 & 0.000 \\
\hline & & & & & & & & & Total $=0.157$ \\
\hline & & & & & (nnovor & twoon $C 4$ & Peel & & \\
\hline
\end{tabular}

\section{Objective Assessment}

\begin{tabular}{|c|c|c|c|}
\hline Assessment of Scars & $\begin{array}{c}\text { Lesions } \\
\mathbf{1 - 1 0}\end{array}$ & $\begin{array}{c}\text { Lesions } \\
\mathbf{1 1 - 2 0}\end{array}$ & $\begin{array}{c}\text { Lesions } \\
\mathbf{> 2 0}\end{array}$ \\
\hline $\begin{array}{c}\text { Mild scarring: 1 point each } \\
\text { Erythematous, hyper- or hypo- } \\
\text { pigmented flat marks } \\
\text { mild atrophy, dish like. }\end{array}$ & 1 & 2 & 3 \\
\hline $\begin{array}{c}\text { Moderate scarring: 2 points each } \\
\text { Moderate atrophy, dish-like } \\
\text { punched out with shallow bases } \\
\text { small scars (<5 mm). Shallow with } \\
\text { broad atrophic areas. }\end{array}$ & 2 & 4 & 6 \\
\hline $\begin{array}{c}\text { Severe scarring: 3 points each } \\
\text { punched out with deep but normal } \\
\text { bases, small scars }\end{array}$ & & & \\
$\begin{array}{c}\text { (<5 mm) Punched out with deep } \\
\text { abnormal bases, small scars (<5mm) } \\
\text { Linear or troughed dermal scarring } \\
\text { Deep broad atrophic areas }\end{array}$ & 3 & 6 & 9 \\
\hline $\begin{array}{c}\text { The Total Acne Scar Score was Calculated as per the } \\
\text { following Criteria }\end{array}$ & \\
\hline
\end{tabular}

\begin{tabular}{|c|c|c|}
\hline Grade & Points & Remarks \\
\hline Nil & 0 & No improvement \\
\hline Satisfactory & 1 & Upto $25 \%$ improvement \\
\hline Good & 2 & $26-50 \%$ improvement \\
\hline Very Good & 3 & $51-75 \%$ improvement \\
\hline Excellent & 4 & $>76 \%$ improvement \\
\hline \multicolumn{3}{|c|}{ Grading of Response was Calculated based on the } \\
Following \\
\hline
\end{tabular}

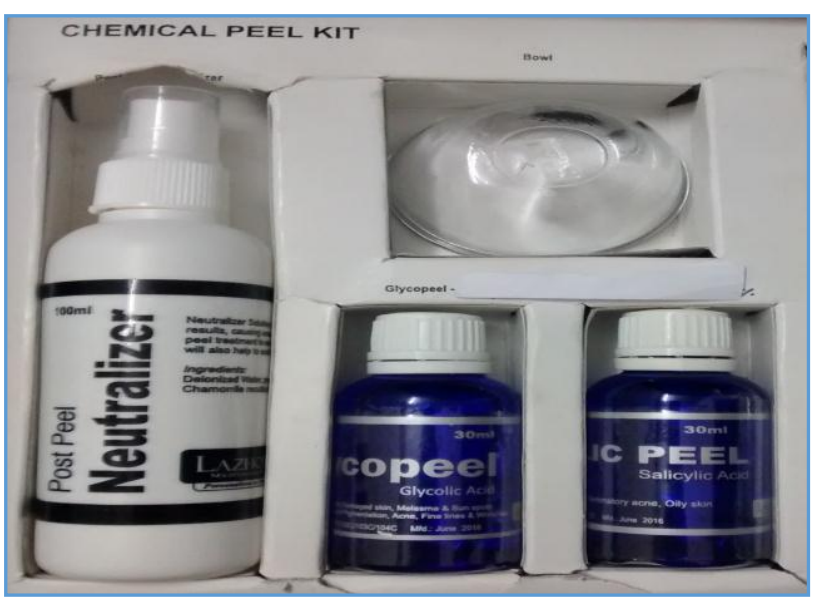

Using a cotton bud, GA peel was applied with smooth strokes over the face in an anti-clockwise manner. After 3-5 minutes depending on appearance of erythema, the peel was neutralised using a neutralisation solution. For SA peel, these patients showed a pseudo-frosting after a contact period of 35 minutes, which was then washed with water. Post acne scars of either sex and willing to participate were included in the study. ${ }^{6}$

\section{The following Patients were excluded from the Study}

Active infections and open wounds on face, patients with unrealistic expectations, tendency of keloid or hypertrophic scar formation, use of isotretinoin in last 6 months, pregnant and lactating females. 


\section{Statistical Analysis}

Chi-square test, student's " $\mathrm{t}$ " test and paired " $\mathrm{t}$ " test was done for the statistical analysis. Software used SPSS v16.0 for statistical analysis.

\section{RESULTS}

7 patients dropped out from the study, 3 from Group A and 4 from Group B. The scores showed a significant decreasing trend from the baseline to the 3rd, 6th, 9th and 12th week of treatment in both the treatment groups. All scores remained almost the same.

\section{Grading of Response by Subject}

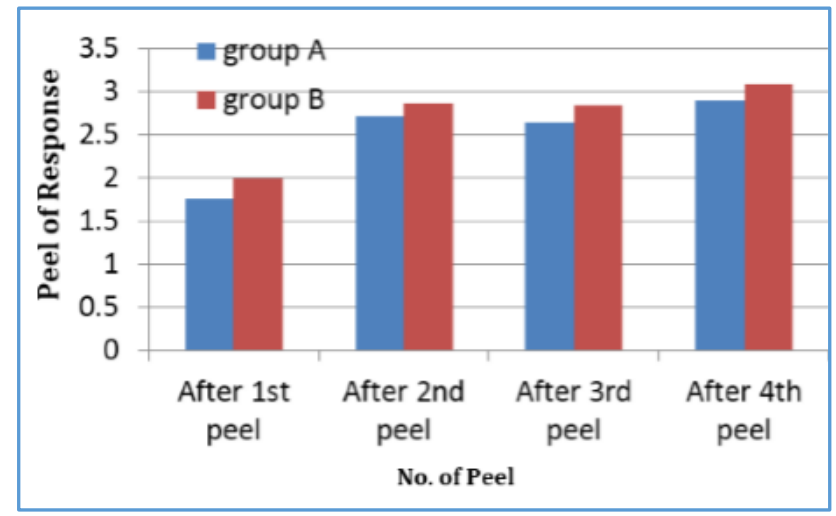

\begin{tabular}{|c|c|c|}
\hline & Group A & Group B \\
\hline Erythema & $12 \%$ & $8 \%$ \\
\hline Burning & $8 \%$ & $10 \%$ \\
\hline Pigmentation & $6 \%$ & $8 \%$ \\
\hline Dryness & $6 \%$ & $5 \%$ \\
\hline \multicolumn{2}{|c}{ Complications } \\
\hline
\end{tabular}

Both SA and GA peels caused significant improvement in post acne scars. Although, SA peels had slightly better outcome when compared to GA peel, the difference was statistically not significant. Side effects were minimal and transient in both the groups.
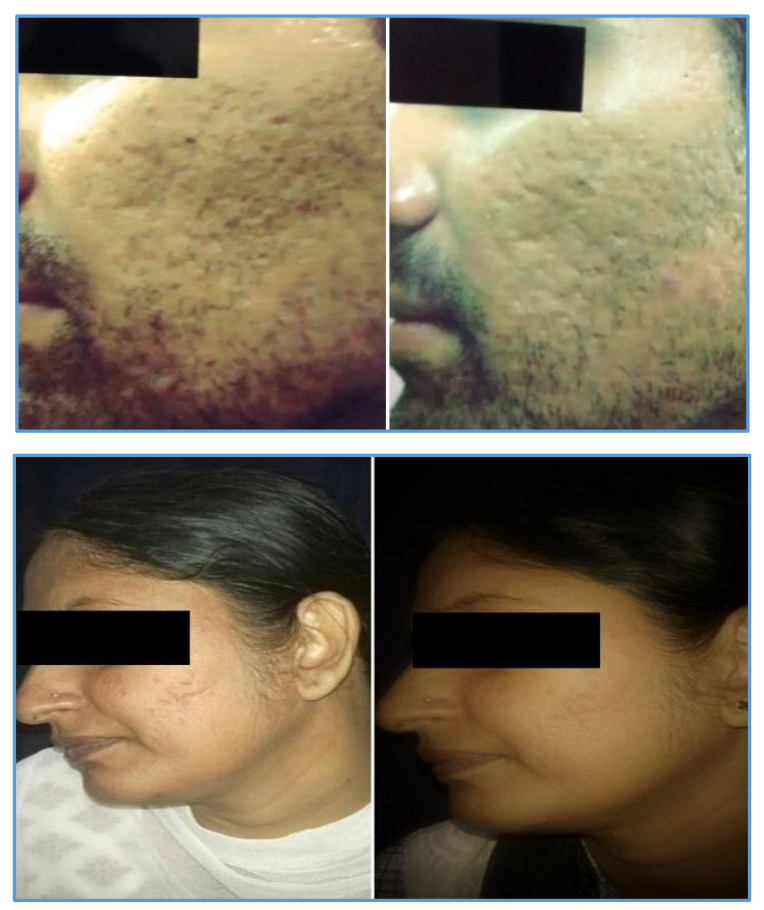

Pre and Post GA Peel
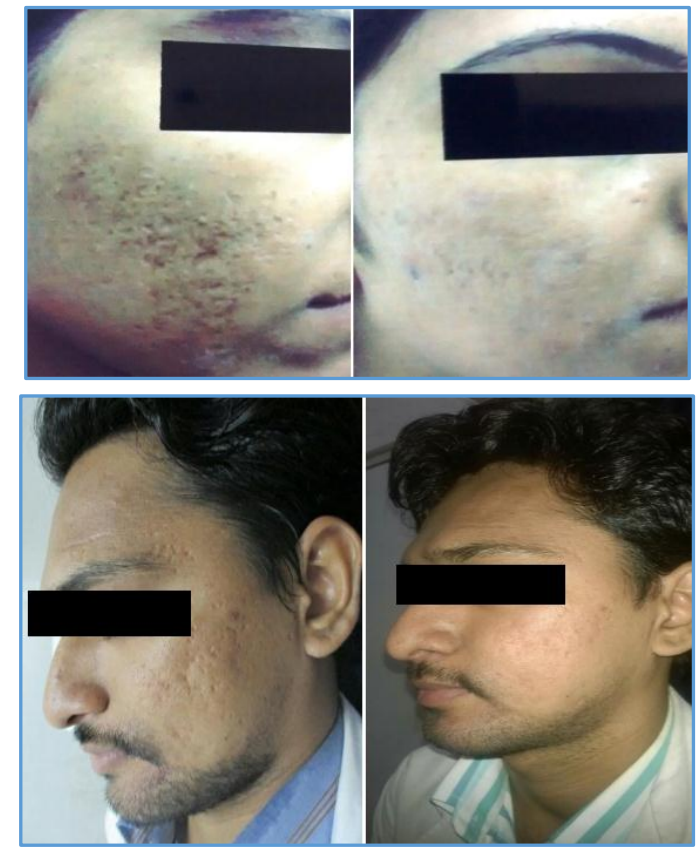

Pre and Post SA Peel

\section{DISCUSSION}

Post acne scarring remains a common entity despite advances in the treatment of acne. Acne scarring patients have greater level of stress, anxiety and psychological depression. It is estimated to reduce the quality of life as great as asthma, diabetic or arthritis. ${ }^{7} \mathrm{~A}$ variety of modalities are available for post acne scarring, out of which chemical peels are: - Effective, safe, painless, non-invasive, easy to perform, cheaper, comedolytic, reduces post acne hyperpigmentation too.

\section{CONCLUSION}

Both Salicylic acid and Glycolic acid are effective and safe in treatment for post acne scars. Scores were better in patients treated with Salicylic acid than Glycolic acid. Differences were not statistically significant. Thus, according to our study, both peels can be used safely with minimal side effects for the treatment of post acne scars.

\section{REFERENCES}

[1] Atal-shah R. Cosmeceuticals. In: Savanth SS, edr. Textbook of dermatosurgery \& cosmetology. $2^{\text {nd }}$ edn. Mumbai, India: ASCAD 2011:64:519-24.

[2] Abraham A. Overview of acne scaring. In: Venkataram M, edr. ACS (I) Textbook on cutaneous \& aesthetic surgery.1 ${ }^{\text {st }}$ edn. New Delhi, India: Jaypee 2012: p. 38691.

[3] Sharad J. Glycolic acid peel therapy - a current review. Clinical Cosmet Investig Dermatol 2013;6:281-8.

[4] Goodman GJ, Baron, JA. Postacne scarring--a quantitative global scarring grading system. J Cosmet Dermatol 2006;5(1):48-52.

[5] Lin AN, Nakatsui T. Salicylic acid revisited. Int J Dermatol 1998;37(5):335-42.

[6] Martin P, Leibovich SJ. Inflammatory cells during wound repair: the good, the bad, the ugly. Trends in Cell Biol 2005;15(11):599-607.

[7] Basta-Juzbasic A. Current therapeutic approach to acne scars. Acta Dermatovenerol Croat 2010;18(3):171-5. 